Snell, E. E. (1953). Physiol. Rev. 33, 509.

Sobel, A. E., Sherman, M., Lichtblau, J., Snow, S. \& Kramer, B. (1948). F. Nutr. $35,225$.

Solvonuk, P. F., Jaques, L. B., Leddy, J. E., Trevoy, L. W. \& Spinks, J. W. T. (1952). Proc. Soc, exp. Biol., N.Y., 79, 597.

Swick, R. W. \& Baumann, C. A. (1952a). Arch. Biochem. Biophys. 36, r2o.

Swick, R. W. \& Baumann, C. A. (1952b). Analyt. Chem. 24, 758.

Thompson, H. T., Dietrich, L. S. \& Elvehjem, C. A. (1950). F. biol. Chem. 184, 75.

Totter, J. R., Martindale, W. E., McKee, M., Keith, C. K. \& Day, P. L. (I949). Proc. Soc. exp. Biol., N.Y., 70, 435 .

Wald, G. (I953). In Symposium on Nutrition, p. 73. [R. M. Herriott, editor.] Baltimore: The Johns Hopkins Press.

Wright, L. D. \& Skeggs, H. R. (1946). Proc. Soc. exp. Biol., N.Y., 63, 327.

Yacowitz, H., Hill, C. H., Norris, L. C. \& Heuser, G. F. (1952). Proc. Soc. exp. Biol., N.Y., 79, 279.

Zechmeister, L. (1937). Ergebn. Physiol. 39, 117.

\title{
Disorders of the Liver in Tropical Nutritional Diseases
}

\author{
By J. Waterlow, Department of Physiology, University College of the West Indies, \\ Jamaica, and Medical Research Council
}

It is now well recognized that liver disease is more common in the tropics than in temperate countries. I think it is reasonable to attribute this to malnutrition, but we cannot regard it as proven. In many instances the relation to diet is not clearcut, and the lesions and their sequence in man do not always resemble those that have been produced by dietary means in animals.

If we leave aside conditions that are undoubtedly caused by infection or infestation, the common types of liver damage may be classified broadly under three heads: fatty liver, fibrosis and cirrhosis, and carcinoma. Of these I shall only consider the first two. As far as I know, massive necrosis or acute atrophy is not more common in the tropics than elsewhere, and therefore I shall not discuss this either.

Fatty liver. This is the most clear-cut form of dietary liver injury in man. It is commonly found in infants and young children, and is a prominent feature of the clinical syndrome of kwashiorkor. The evidence that the fatty liver is caused by malnutrition may be summarized as follows:

It typically comes on after weaning, at a time when the diet is grossly deficient; it is accompanied by oedema, hypoproteinaemia, and often by signs of various vitamin deficiencies; there is no constant relation to any infection or parasitic infestation; lastly, it responds to treatment by dietary means alone.

Admittedly, there is nothing specific about a fatty liver per se. It may be found in infants dying of many diseases, notably gastro-enteritis and tuberculosis. What does seem to be specific about the fatty liver of kwashiorkor is its intensity. The fat content is often $40 \%$ of the wet weight, and may even rise to $50 \%$-as much as, or more than, that resulting from diets producing the most intense fatty liver in animals. 
Although the evidence is strong that this is a dietary lesion, we still do not know the exact nature of the deficiency that causes it. No well-controlled trials of lipotropic factors have ever been made, but the results that have been obtained with choline, methionine and inositol are not encouraging. Davies (1948) has suggested that the fatty liver may be secondary to the atrophy of the external secretory tissue of the pancreas that is constantly found in these cases. All authors agree that the best treatment is milk. At present we can but regard the fatty liver as one manifestation of 'protein malnutrition'- - a term that has been introduced to describe the effects of deficiency of protein, both quantitative and qualitative, and of factors which may be associated with protein in the diet (FAO/WHO: Expert Committee on Nutrition, 1952).

This concept drives home the point that we are dealing with more than just a liver disease. The whole body is undernourished and presumably protein-depleted. We see this in the blood, where there is hypoproteinaemia, in the muscles which are grossly wasted (Waterlow, I948), and in the pancreas and gut which show atrophy of the secretory cells (Waterlow, I948; Davies, 1948, 1952). Some years ago I ventured the generalization that, according to the clinical and pathological evidence, the organs that are earliest and most severely damaged are those which we know from experimental work to have the highest protein turnover (Waterlow, I949). This fits in well with Dr Munro's (1954) remarks.

When I first worked on these cases I thought that, although the whole body was affected, the fatty liver was the key factor that determined the severity of the case and the high mortality. Since then $I$ have been able to measure the amount of fat in liver-biopsy specimens. The results so obtained do not confirm the original idea. The patients that die are not necessarily those with the highest liver fat. Moreover with treatment the liver fat returns to normal in 3 or 4 weeks, but the child may still remain severely ill for weeks or even months afterwards. Some factor other than the presence of excess fat in the liver must, therefore, be involved. It is reasonable to suppose that this factor, on which the severity and course of the disease depend, might be the degree of protein deficiency or depletion of the body. This is difficult to measure in the body as a whole, but some evidence can be gained from a single organ, e.g. the liver. That the liver is fatty is no reason why it should not also be protein-depleted. Measurements made at autopsy show that the total amount of protein in these fatty livers may be little more than half the amount expected for a baby of the same age. Since we have no means of finding the total liver weight in the living subject, measurements made on biopsy specimens must all be related to deoxyribonucleic acid (DNA) as a standard. Table $\mathrm{I}$ shows the results of such measurements made in Jamaica on twelve consecutive cases.

In the malnourished liver both ribonucleic acid (RNA) and protein are reduced by about $40 \%$. This finding fits in well with the results obtained in experimental animals that have been starved or fed on a protein-free diet (Addis, Poo \& Lew, I936; Kosterlitz, I947; Munro \& Naismith, I953; Thomson, Heagy, Hutchison \& Davidson, 1953). Equal degrees of protein depletion may be found in livers with no excess fat. At present I am therefore inclined to regard the fatty change as 
Table I. Content of protein and nucleic acid of the liver in malnourished infants (twelve cases). Measurements made on biopsy specimens

\begin{tabular}{|c|c|c|c|}
\hline & $\begin{array}{c}\text { DNAP* } \\
(\mu g / \mathrm{mg} \text { fat-free dry } \\
\text { weight })\end{array}$ & $\begin{array}{l}\text { Protein nitrogen } \\
(\mathrm{mg} / \mathrm{mg} \text { DNAP*) }\end{array}$ & $\begin{array}{c}\text { RNAP† } \\
(\mathrm{mg} / \mathrm{mg} \mathrm{DNAP*})\end{array}$ \\
\hline Before treatment & $\mathrm{I} \cdot 73$ & $49 \cdot 7$ & 1.05 \\
\hline After treatment & I.I 5 & $80 \cdot 3$ & 1.59 \\
\hline Difference & $-0.5^{8}$ & 30.6 & 0.54 \\
\hline
\end{tabular}

a phenomenon of relatively little importance except perhaps in extreme cases, when it may cause circulatory impairment. It remains to be seen whether measurements of this kind made on the liver can give us any information about the degree of depletion of the body as a whole.

Fibrosis and cirrhosis. Here the picture is complicated and confused: 'tropical cirrhosis' is not a single entity. Many different types of hepatic fibrosis and cirrhosis have been described in different tropical countries. The commonest form in autopsy material is the ordinary Laennec's cirrhosis; in addition there is pigment cirrhosis in South Africa (Gillman \& Gillman, I95r), 'stellate' or monolobular fibrosis in East Africa (Vint, I93 I; Davies, I948), pericellular, so-called 'biliary', cirrhosis of infants in India (Rao, 1933) and cirrhosis following 'serous hepatosis' or venous occlusion in Jamaica (Hill, Rhodes, Stafford \& Aub, I953; Bras, Jelliffe \& Stuart, I954).

It is probable that the same end-result-a diffuse cirrhosis of the Laennec type - can be produced by different pathological sequences. By analogy with rat experiments it seems reasonable to suppose that, in some cases at least, the initial lesion might be the heavy fatty infiltration that is common in infants. However, there is no proof of this hypothesis and much evidence against it. As far as I am aware, no account has yet been published showing in man all stages of the transition from fatty infiltration to fibrosis such as can easily be demonstrated in the rat. If indeed this sequence does occur one would expect to find it in childhood since the initial lesion-fatty infiltration-is most severe in the early years of life. But geographically there seems to be little correspondence between the incidence of fatty liver and of juvenile cirrhosis, as is shown in Table 2. This table does not pretend to be comprehensive, but is intended merely to point out exceptions that have to be explained.

I have personal experience of two of the places mentioned in this table - the Gambia and Jamaica - and will therefore consider this material in more detail. In the Gambia three types of fibrosis were found in a fairly large series of liver biopsies in infants and children (Walters \& Waterlow, r954). The first was a localized peri-portal or monolobular fibrosis which was very common even in apparently normal children. The second was a peri-portal fibrosis in a more active stage, with an early invasion of the parenchyma by fibrous tissue. It was found particularly 
Table 2. Frequency in different parts of the world of fatty liver and of cirrhosis in infants and children

\begin{tabular}{|c|c|c|c|}
\hline Country & Fatty liver & Cirrhosis & Authority \\
\hline S. Africa & + & \pm & Gillman \& Gillman (195I)* \\
\hline Uganda & + & \pm & Davies (1948) \\
\hline Gambia & o & + & Walters \& Waterlow (1954) \\
\hline Brazil & + & o & $\begin{array}{l}\text { Carvalho, Pinto, Schmidt, Potsch \& Costa } \\
\text { (1945); Fraga Filho (1953) }\end{array}$ \\
\hline Curacao & + & 0 & Van der Sar (195I) \\
\hline Chile & + & 0 & Meneghello (I949) \\
\hline India & + & + & Rao (1933); Achar (1950) \\
\hline Jamaica & + & + & Waterlow (1948); Hill et al. (1953) \\
\hline
\end{tabular}

* Although cirrhosis of the liver is common in adults in Johannesburg, Gillman \& Gillman (1951), in an extensive series, do not record a single case in the first two decades of life. They do not believe that fat has any causal relation to the development of fibrosis or cirrhosis.

in infants. The livers, however, were not fatty. The third type was a diffuse fibrosis, with distortion of the architecture, going on to a true cirrhosis. Examples of this were found at all ages above 3 years.

The general level of nutrition in the Gambia seems to be no worse than that in many other countries; it was therefore difficult to regard this condition, which, by comparison with other places, seemed to be both precocious and severe, as a purely dietary injury. The clinical and epidemiological evidence suggested that a combination of two factors might be involved-malnutrition and malaria. We suggested that malnutrition damages the parenchyma and tends to stimulate fibrosis, but this stimulus is ineffective unless the reticular cells which lay down the fibres have been made hyper-reactive by some other stimulus such as malaria. In infants in the Gambia both these stimuli are operative; during the 2nd year of life, after weaning and before the baby is able to take mixed food, it passes through a critical period during which it gains no weight and may become severely malnourished. At the same time it is exposed to malaria which is hyper-endemic; it has lost its maternal immunity and not yet developed its own, so that malaria is often active and severe. The mortality from these two causes during the 2nd year of life is high. If the child does not die the fibrosis that had begun in the liver usually settles down, leaving only residual scars. In a minority of cases where conditions are adverse, this does not occur and the lesion remains active and progressive. This hypothesis thus involves damage by two agents to the two main tissues of the liver, the epithelium and the connective tissue.

A similar theory has been put forward by Bras to explain the occurrence of juvenile cirrhosis in Jamaica (Bras et al. 1954). He has shown that the initial lesion in the liver is an endophlebitis of the small hepatic veins, and has named the condition 'venous occlusive disease'. The vascular obstruction leads to a centrilobular fibrosis, which may go on to a fully developed cirrhosis. This vascular lesion has not, so far as I know, been produced experimentally by dietary means, but similar changes can be caused by various poisons including the senecio alkaloids 
(Selzer, Parker \& Sapeika, 195I). It is possible that children in Jamaica might be exposed to toxic factors of this kind, since from an early age they are given bush teas-that is, infusions of local plants. At the same time, Rhodes (1952) has shown that the children in whom this liver lesion develops present evidence of chronic and marginal malnutrition, and that their diet is very low in protein. Thus it seems possible that in these children ingested toxins are able to damage a malnourished but not a normal liver. This suggestion recalls the experimental work of Miller \& Whipple (1940) some years ago.

These two examples illustrate the complexity of the problems with which we are faced in any attempt to disentangle the causes of hepatic fibrosis and cirrhosis in the tropics.

\section{REFERENCES}

Achar, S. T. (1950). Brit. med. F. i, 7or.

Addis, T., Poo, L. J., \& Lew, W. (I936). F. biol. Chem. Ir5, I I .

Bras, G., Jelliffe, D. B. \& Stuart, K. L. (1954). Arch. Path. 57, 285.

Carvalho, M., Pinto, A. G., Schmidt, M. M., Potsch, N. \& Costa, N. (1945). F. Pediat., Rio de f., Ir, 395 .

Davies, J. N. P. (1948). Lancet, 254, 317.

Davies, J. N. P. (1952). Annu. Rev. Med. 3, 99.

FAO/WHO: Expert Committee on Nutrition (1952). Tech. Rep. Wld Hlth Org. no. 44.

Fraga Filho, C. (1953). Personal communication.

Gillman, J. \& Gillman, T. (r95 I). Perspectives in Human Malnutrition. New York: Grune \& Stratton.

Hill, K. R., Rhodes, K., Stafford, J. L. \& Aub, R. (I953). Brit. med. F. i, I 7.

Kosterlitz, H. W. (1947). F. Physiol. ro6, 194.

Meneghello, J. (1949). Desnutrición en el Lactante Mayor. Santiago de Chile: Central de Publicationes.

Miller, L. L. \& Whipple, G. H. (1940). Amer. F. med. Sci. 199, 204.

Munro, H. N. (1954). Proc. Nutr. Soc. 13, (1 15).

Munro, H. N. \& Naismith, D. J. (1953). Biochem. F. 54, 19 r.

Rao, M. V. R. (1933). Indian F. med. Res. 21, 389.

Rhodes, K. (1952). Brit. F. Nutr. 6, I98.

Selzer, G., Parker, R. G. F. \& Sapeika, N. (1951). Brit. F. exp. Path. 32, 14.

Thomson, R. Y., Heagy, F. C., Hutchison, W. C. \& Davidson, J. N. (1953). Biochem. F. 53, 460.

Van der Sar, A. (1951). Docum. neerl. indones. Morbi trop. 3, 25.

Vint, F. W. (1931). Kenya med. Y. 7, 349 .

Walters, J. M., \& Waterlow, J. C. (1954). Spec. Rep. Ser. med. Res. Coun., Lond. (In the Press.)

Waterlow, J. C. (1948). Spec. Rep. Ser. med. Res. Coun., Lond., no. 263.

Waterlow, J. C. (I949). In paper by Trowell, H. C. (1949). Trans. R. Soc. trop. Med. Hyg. 42, 417 (Discussion).

\section{Dietetic Aspects of the Treatment of Liver Disease}

By A. L. LAtner, Section of Chemical Pathology, Department of Pathology, King's College and The Royal Victoria Infirmary, Newcastle upon Tyne

\section{General considerations}

Rest. Regardless of dietetic considerations, there seems little doubt that one of the most important factors in the treatment of liver disease is adequate bed rest. It is now known that the circulation to the liver is decreased by the upright position 